become more important in the tropics in the future. Subsequent speakers at this meoting added their experience in industry to support Dr. Macdonald's views. It is evident from these speeches that the industrialist is well aware of the industrial need for, and the value to industry of, modern methods of control of disease. Brig.-General F. D. Hammond, indeed, said that hitherto the main support for tropical hygiene had come from commercial undertakings rather than from Governments. Tropical hygiene should, he thought, take priority over everything else because, unless the inhabitants are healthy, it is no use talking about development. Dr. Macdonald, in his reply, pointed out that the Colonial Development and Welfare Act allowed for an expenditure of 120 million pounds during the next ten years, with a maximum expenditure of seventeen and a half millions in any one year. The Secretary for the Colonies had stated that part of this money would be spent upon the development of health and education, and it was laid down that not more than one million in any one year should be spent upon research and inquiry of all kinds. Only a proportion of this sum, therefore, would go to medical research. Mr. C. R. Harrison, however, revealed that in Mauritius, at any rate, a "very large proportion" of the money received from the Colonial Development Fund will be devoted to hygiene and particularly to the control of malaria. It is to be hoped that other areas will copy this fine example.

G. LAPAGE.

\section{INTER-UNIVERSITY COUNCIL FOR HIGHER EDUCATION IN THE COLONIES}

$\mathrm{I}_{\mathrm{N}}^{\mathrm{N}}$ accordance with the recommendation of the Commission on Higher Education in the Colonies (see Nature, Sept. 22, 1945, p. 345), the Government invited the universities of the United Kingdom, the University of Ceylon, the Hebrew University, Jerusalem, and the Royal University of Malta, to nominate representatives to serve on a body to be known as the Inter-University Council for Higher Education in the Colonies. All these universities accepted the invitation and their representatives, together with the educational adviser to the Secretary of State for the Colonies, met for the first time in London, on March 8, when the Council was formally set up. The members of the Council are: Sir William Hamilton Fyfe, vice-chancellor and principal, University of Aberdeen; Prof. R. G. Baskett, professor of agricultural chemistry, University of Belfast; Dr. R. E. Priestley, vice-chancellor and principal, University of Birmingham; Mr. P. R. Morris, vicechancellor, University of Bristol; Dr. J. A. Venn, president, Queens' College, Cambridge ; Dr. W. Ivor Jennings, vice-chancellor, University of Ceylon; Dr. J. F. Duff, vice-chancellor, University of Durham; Prof. John Macmurray, professor of moral philosophy, University of Edinburgh ; Prof. Noah Morris, regius professor of materia medica and therapeutics, University of Glasgow; Prof. Norman Bentwich, professor of international relations, Hebrew University, Jerusalem; Mr. B. Mouat Jones, vice-chancellor, University of Leeds; Prof. J. G. Wright, professor of veterinary surgery, Univer. sity of Liverpool; Sir Alexander Carr-Saunders, director, London School of Economics and Political
Science; Prof. Robert V. Galea, rector, Royal University of Malta ; Prof. W. J. Pugh, deputy vicechancellor and professor of geology, University of Manchester; Dr. W. T. S. Stallybrass, pro-vicechancellor, University of Oxford; Prof. R. H. Stoughton, professor of horticulture, University of Reading; Sir James Irvine, vice-chancellor and principal, University of St. Andrews; Prof. L. E. S. Eastham, professor of zoology, University of Sheffield ; Mr. Ifor L. Evans, principal, University College of Wales, Aberystwyth ; Mr. C. W. M. Cox, educational adviser to the Secretary of State for the Colonies. The secretary of the Council is Mr. Walter Adams. Sir James Irvine was elected chairman and Sir Alexander Carr-Saunders vice-chairman.

The Council's objects are stated in its constitution and terms of reference to be $(a)$ to strengthen cooperation between the universities of the United Kingdom and the existing universities in Colonial territories : (b) to foster the development of higher colleges in the Colonies and their advance to university status; and (c) to take such other action as will give effect to the principles recommended by the Commission as appropriate for the promotion of higher education, learning and research in the Colonies. It will also be noted that a full-time secretary has been appointed to serve the Council; he will also serve the Colonial University Grants Advisory Committee, which is being established as an advisory body to the Secretary of State, as recom. mended by the Commission. Two members of the new Council will also serve on the Grants Committee. It is also hoped that members of the Council will obtain first-hand experience of the development and needs of Colonial universities. It is hoped, too, that the Council will be ready to advise Colonial institutions of higher education on matters of academic policy, including questions relating to research work in such institutions. On questions of research it is assumed that the Council will maintain liaison with the Colonial Research Committee and other research bodies set up by the Secretary of State.

To welcome the Inter-University Council at its first meeting, Mr. G. H. Hall, Secretary of State for the Colonies, sent a message, in the course of which he said that the Government is pledged to quicken the social, economic and political progress of Colonial peoples and to guide them towards the ultimate goal of self-government. The success of this policy will depend on the emergence, in every Colonial territory, of increasing numbers of educated men and women with the technical training, the ability and the desire to serve their communities as leaders in every sphere of public life. The establishment of further universities in the Colonial territories can contribute greatly towards the achievement of this goal, and in furtherance of this task the Government has allocated $£ 4,500,000$ for higher education in the Colonies during the next decade. Mr. Hall also expressed the hope that although universities in Britain are facing grave difficulties in finding staff and in restoring themselves after the great efforts which they made in the War, they will be able to discover means of lending some of their own members to assist the development of the new university colleges, particularly in their early stages. He also referred to the jealous care with which universities guard their autonomy and freedom from governmental interference, and added that he was sure that in such freedom the Council could better discharge the great tasks it has undertaken. 